Portland State University

PDXScholar

Summer 8-30-1974

\title{
Labor Violence: the Centralia Case, the IWW and its Enemies
}

Lawrence C. Skoog

Portland State University

Follow this and additional works at: https://pdxscholar.library.pdx.edu/open_access_etds

Part of the United States History Commons Let us know how access to this document benefits you.

Recommended Citation

Skoog, Lawrence C., "Labor Violence: the Centralia Case, the IWW and its Enemies" (1974). Dissertations and Theses. Paper 2300.

https://doi.org/10.15760/etd.2297

This Thesis is brought to you for free and open access. It has been accepted for inclusion in Dissertations and Theses by an authorized administrator of PDXScholar. Please contact us if we can make this document more accessible: pdxscholar@pdx.edu. 
AN ABSTRACT OF THE THESIS OF Lawrence C. Skoog for the Master of Arts in History presented August $30,1974$.

T1tle: The Centralla Incldent: Oral H1story and Historical Reconstruction

APPROVED BY MEMBERS OF THE THESIS COMMTTEE:

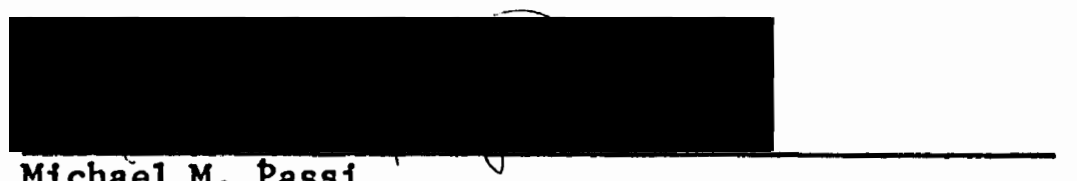

Michael M. Passi

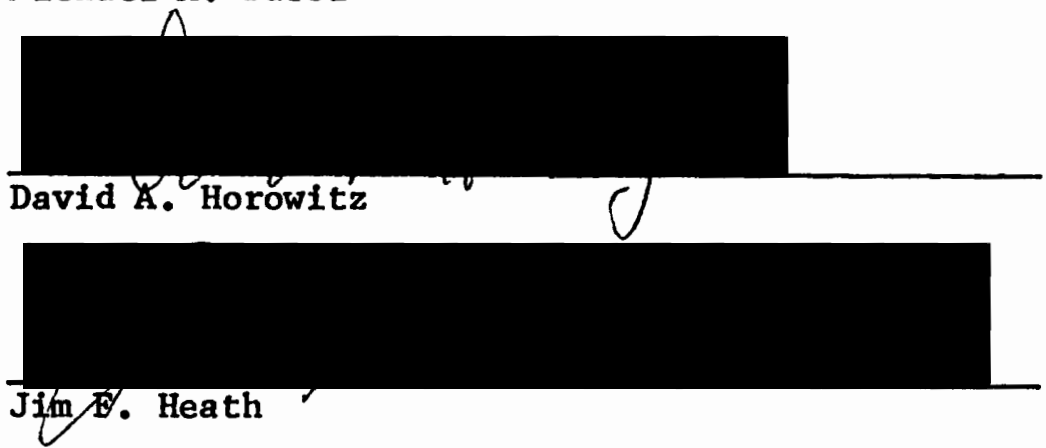

,

Armistice Day 1919 was enthusiastically celebrated in Centralia, Washington. The principle event of the day's activities wals a parade organized under the leadership of the newly formed American Legion. But the parade was to be more than the simple affirmation of the victory in France, it was to be a reaffirmation of the patriotism of the newly returned sailors and soldiers and their home-town supporters. 
Centralia was a troubled city in 1919. Organized labor of the most militant and extreme sort was challenging the oligopoly of the lumber trust. The Industrial Workers of the World had been successful in their strike of 1917 and had worked significant and widespread changes in the wage and work conditions then effective in the lumber camps of the pacific northwest. These "Wobblies" had established an office in Centralia which was a principle transit site for both the lumber camps working in the Cowlitz River foothills and the incredibly rich Grays' Harbor district. Loggers bound in and out of this location had a stop over in Centralia where they were proselytized by the firey orators of the IWW.

Reactionary elements within the American Legion and the Elks lodge resolved to use the assembled veterans marching in the Armistice Day parade to accomplish a raid upon the IWW hall as had been done a year earlier spontaneously during a Red Cross parade in the city. The plans of the plotters became known to the IWW who attempted to secure police protection. When official aid was denied, the IWW members resolved to protect their hall themselves. The result was three separate riots. The first riot was the actual raid upon the hall and resulted in the death of three members of the marching contingent of veterans. The second riot was the spontaneous reaction of the veterans and the townspeople of Centralia to pursue and capture the members of the IWW responsible for the armed resistance 
to the raid. This action led to one further death and the severe beating of a number of captured IWW members. The third riot of the day was the planned storming and removal of Wesley Everest, a captured IWW member who was deemed mistakenly to have led the "Wobblies" in their efforts to resist the violators of their hall. Everest was castrated, lynched and shot to death the night of November 11, 1919.

The affidavits used as the bulk of the primary evidence for this thesis constitute a valuable "oral" document which if properly used can reveal an important aspect of the Centralia case not present in the formally written accounts of the event. The various affiants bring a sense of immediacy, vitality, horror and disgust that can only be simulated in literary accounts. The bulk of the oral evidence alone allows the historian to apply approved standards of verification. The Becker Committee affidavits give us a useful and unique resource for attempting to present the tragic events of November 11 , 1919 in Centralia, Washington. 
LABOR VIOLENÇE: THE CENTRALIA CASE,

THE IWW AND ITS ENEMIES

by

LAWRENCE SKOOG

A thesis submitted in partial fulfillment of the requirements for the degree of

\author{
MASTER OF ARTS \\ in \\ HISTORY
}

Portland State University

1975 
TO THE OFFICE OF GRADUATE STUDIES AND RESEARCH:

The members of the Committee approve the thesis of Lawrence A. Skoog presented August 30, 1974.

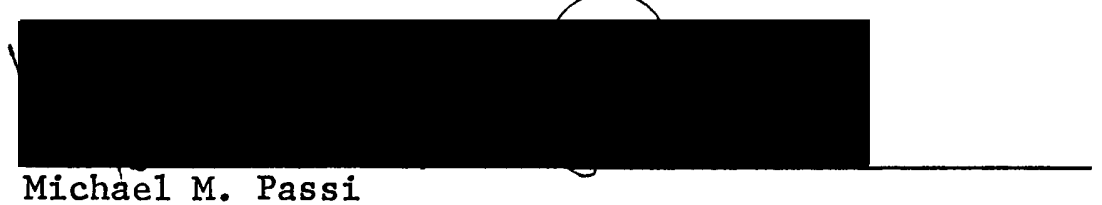

Michae1 M. Passi
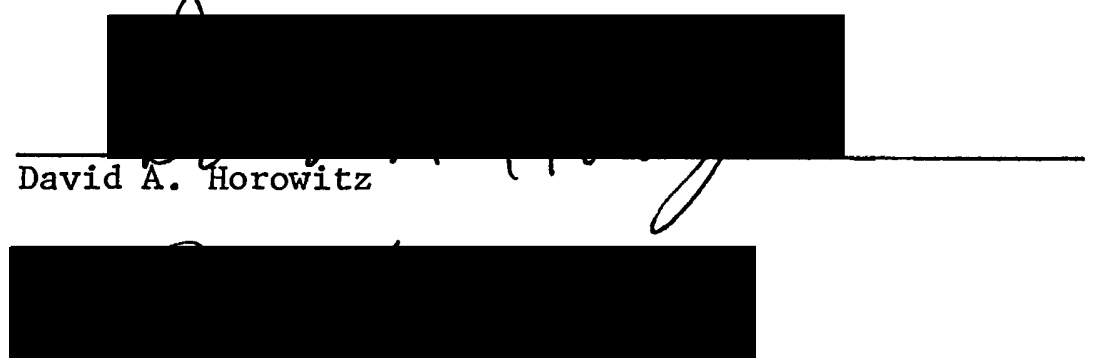

Jim Heath

\section{APPROVED :}

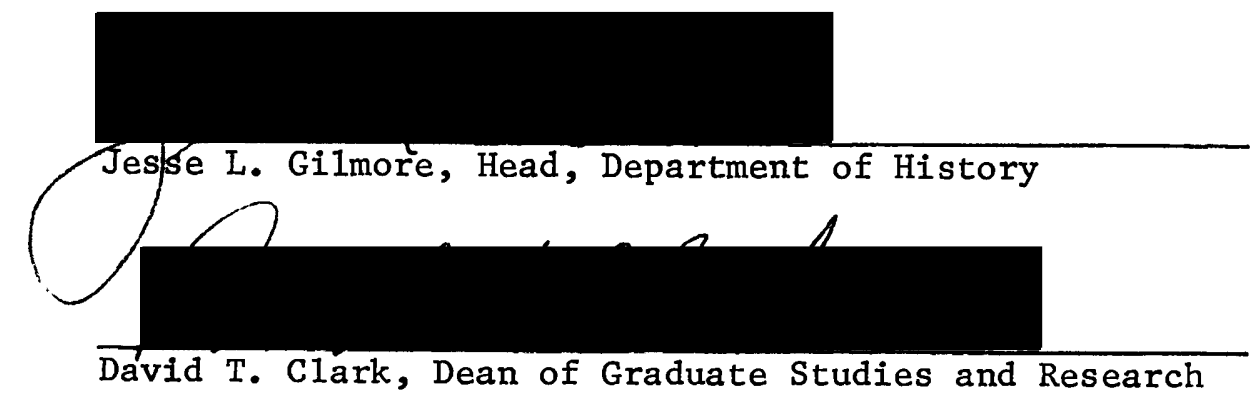




\section{TABLE OF CONTENTS}

\section{PAGE}

CHAPTER

I INTRODUCTION . ............................ 1

II THE SETTING . . . . . . . . . . . . . . . . 9

III VIOLENCE ON TOWER AVENUE . . . . . . . . . 17

IV REACTION . . . . . . . . . . . . . 33

V CONCLUSION 


\section{CHAPTER I}

\section{INTRODUCTION}

Historians have had great difficulty in dealing with the Centralia incident. ${ }^{1}$ Nothing seems to have come of this episode which cost the lives. of five men and the wounding of at least 15 others. Industrial Workers of the The World partisans identify the events of November 11, 1919, as the Centralia Conspiracy. Supporters of the American Legion call them the Centralia Outrage. Somewhere between Conspiracy and Outrage lies the truth.

Centralia represents the final decline of the transitory influence of anachro-syndicalism in the northwest woods. The inability of the Wobblies to defend themselves successfully from attack demonstrated the poverty of-the Wobs to muster sufficient manpower at a location where they had for knowledge of :jmpending trouble. Centralia was not

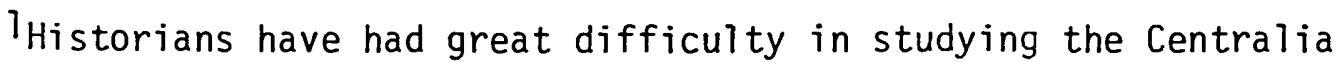
raid. It is one of those difficult events which make no apparent sense and which seem to lead to nothing. John M. McClelland Jr. offers what has become the standardized wisdom when discussing the event in his "Terror on Tower Avenue," an article appearing in the Pacific Northwest Quarterly, Vol..57, No. 2, April, 1966. Virtually every scholarly article, monograph, book length treatment and thesis dealing with the IWW in the western woods uses McClelland as the basis for the investigative research if it was published after the article appeared in Pacific Northwest Quarterly in Vol. 57, No.2, April, 1966. Those mentions of Centralia, the shootout, lynching and the subsequent trial that antidate the McClelland study are brief and cursory in their approach. Centralia stands as an incident that requires more time, investigative skill and a more preceptive use of research skills than has been previously applied. 
Spokane, Aberdeen or Everett where the union had been able to bring to bear. large numbers of men in situations that were equally dangerous. After Centralia, the IWW was unable to conduct anything more than a successful job action strike. The class war prison strike of 1924 was a dismal failure which accomplished nothing for the IWW save to firmly plant the tombstone on its grave. After Centralia the IWW was an anachronism in the western woods.

Centralia then must be viewed as a victory for the lumber manufacturers and the timber barons whose powers would be unchecked until the successful organization of the CIO in the woods. The battle that was fought so briefly on Tower Avenue during the afternoon of Armistice Day was, in effect, a battle between capital and labor for the control of the lives of thousands of men who worked in the woods.

What was it about Centralia that so effectively broke the back of the IWW in Washington? The answer is simple, terror. Sustained violence breeds terror, terror that numbs the intellect, terror that brings even the most courageous to their knees. Terror that springs from the cold and calculated lynching of a man after castration. The psycho-sexual impact of this act was tremendous, spoken of in hushed tones appropriate to the Victorian modesty of the day. One frequently finds this same tactic used against blacks in the South during the same period. Spokane saw mass jailings; Aberdeen, deportation; Everett, shooting from ambush; Centralia, lynching, beatings, castration. 
Studies by Herbert Gutman and others indicate that community support for labor organization was fairly general and positive, especially in western America. Was this situation different in Centralia? How was it possible that an entire community could come to rank itself against a labor organization which while admittedly radical, ${ }^{2}$ actively disavowed political action and whose stated aims in Centralia were to organize an itinerant labor force who used Centralia only as a way station while travelling to and from their employment. The Industrial Workers of the World were perceived to threaten something important to Centralia, what was the nature of that threat? How did the community arrive at confrontation with the union, what models for action influenced action, what were the ideas expressed which mobilized veteran and nonveteran, anti unionists and trade unionists, small businessmen and entrepenuers without regard for social class, economic rank or political persuasion to unite to drive the IWW from Centralia in a violent mob action.

The primary evidence used in the preparation of this thesis comes from a unique collection of affidavits collected by the "Free Ray Becker Defense Committee" _in the ]ate 1930s.. Ms. Julia Godman Bertram Rutilla was the secretary of the committee which was made up of officers and members of the International Woodworkers of America and

${ }^{2}$ See Joseph Robert Conl in, Bread and Roses, Too Studies of the Wobblies, Greenwood Publ. Corp. 1969, for a lively discussion of the philosophical and intellectual basis of the IWW. 
financed by them to work for the freedom of the last convicted IWW member still behind bars at Walla Walla State Penitentiary in Washington. The defense committee assembled extant evidence and affidavits relating to the case including materials collected by Elmer Smith immediately after his acquital of murder charges stemming from the Centralia case. 3

Legal affidavits are in a sense a kind of oral history. They are a statement of fact attested to by oath, stenographically recorded, in many cases in the language of the informant. They are reviewed and approved by the informant after transcription and finally sworn to under mandate of the law. I have decided to use the oral historian's criteria for veracity and value in judging the usefuiness of the Becker Affidavits. Was the informant in a unique position to have special knowledge of the event in question? Is his or her testimony corroborated by one or more independent witnesses? In the case of the Becker Affidavits the answer in both cases is almost always yes. 4

It must a]ways be remembered that Oral History is history that is collected in a unique manner. Two predominate schools of oral Historians are in dispute as to the best uses of the technique... One

${ }^{3}$ Affidavits were collected by Elmer Smith, Julia Godman Bertram Ruutilla, Irwin Godman and other temporary employees of the committee to Free Ray Becker. The collection of affidavits proceeded in 3 primary periods $; 919-24, \div 1930$ and 1936. The first period coincides with the event, the second with the issuance of the Federal councils report and the third with the pressures mounted within the IWA for Becker's release.

${ }^{4} A$ number of recent studies have given Oral Historians direction, substance and thrust. Perhaps the finest effort to date is william Montell's, The Saga of Coe Ridge, University of Tennessee Press, 1970. 
tendency believes that oral history is a means by which an interviewer might penetrate the personality and visceral remembrance of so called "great men." This notion is best exemplified by the work of Allen Nivens, The Columbia Oral History Project, Wilma Baum and the various presidential libraries. Lists are prepared of the important figures surrounding events, ideas, and social movements. The individuals who comprise these lists are interviewed by historians who have carefully prepared themselves and usually furnished their informants with a series of prepared questions as a guide line for the series of interviews. This kind of approach closely parallels the traditional activities of historical research. Spontaneity is not encouraged save inside the parameters of the assigned question. The argument here is that tight control provides more important information and avoids digressions. This form of interview most closely approximates the technique of the interviewers who collected the Centralia affidavits.

The second major tendency has been loosely called the "Open Mike" technique or the "little man" approach. Here the criteria in selection of informants is based on the kind of information desired by the researcher: A major effort is made to locate significant participants in events, movements and decisions who are not likely to leave any kind of written corpus behind them. The emphasis is placed on the non-literary, unsophisticated informant who might by his placement have observed events in a special way. The actual interviewing technique is much different from those using the more formal method described 
above. A gentle sort of guiding is done by an interviewer familiar with the broad outlines of the subject matter of the interview. Digression is allowed, even encouraged when it appears to be leading in a fruitful direction. There are hints of this kind of approach in several of the Centralia Affidavits, especially when an affiant is allowed to express a feeling or opinion. This researcher would have hoped to find more data which would expose the personalities of the affiants so as to judge their mental attitudes more accurately.

If we view the Centralia Affidavits as a kind of primitive effort to collect oral history we must apply the standard tests of that obtain in any use of orally collected historical data. The first and foremost of these tests is the test of corroboration. How many of the Affidavits support each other by the repetition of detail found in one or more additional affidavit? This test when applied to the Centralia affidavits is not entirely satisfactory since the affidavits were collected with a specific purpose foremost in the minds of the collectors--the freeing of the convicted IWW members involved in the Centralia affair. Thus, this collection includes only those affidavits which support certain basic contentions of the defense council, that the American Legion conducted a premeditated raid on the IWW hall which was lawfully resisted and that there existed a conspiracy to drive the IWW from the city of Centralia. When weighing the data in view of these preconceptions, the affidavits still stand as unique documents, rich in detail which are mutually supportive. It is hard to see how the capture of Wesley 
Everest could have occured in any way save that retold in the Clark Clifford Affidavit and supported in several other affidavits.

The second major test is to view the data collected against traditional published accounts. In the Centralia case we have three interpretive documents ${ }^{5}$ produced by widely varying interest groups. Centralia: Tragedy and Trial by Ben Hur Lampman was a frankly partisan booklet produced at the direction of the American Legion by a legion member who later became an editor of the Portland Oregonian. Lampman's account is reliable in certain details but presents only that evidence which supports his particular advocacy. It overflows with "patriotic gore," flag waving and talk of fallen heroes. Ralph Cahplin's The Centralia Conspiracy is the opposite number to Lampman's effort in many respects. Chaplin was at the time of the Centralia case the principle propagandist for the IWW. A poet and song writer, he sees only the IWW side of the case and creates a mythology of "working class hero" around the convicted IWWs. The Centralia Case, a joint effort produced by the Federai Council of Churches of Christ in America, the Social Action Department of the National Catholic Welfare Conference, and the Social Justice Commission of the Central Conference of American Rabbis is a reasonable-balanced document which understandably is concerned with

5 Ben Hur Lampman; Centralia: Tragedy and Trial, a joint-publication of Frank Hodge, Post No. 17, Centralia, Washington, and Edward B. Rhodes, Post No. 2, Tacoma, Washington, 1920. Ralph (H.) Chaplin, The Centralia Conspiracy, General Defense-Fund--IWW, Chicago, 1920, ist Edition. The Centralia Case: A Joint Report of the Federal Council of. Churches of Christ. - The Social Action Department of the Nationa? Catholic Welfare Conference and the Social Justice Commission of the Central Conference of American Rabbis, 1930. 
the moral issues involved with the case. As one might expect given the stated purpose of the collection of the affidavits they are most closely supported by the Chaplin version of the events of November 11, 1919. However, there is sufficient similarity between the Lampman material, the Chaplin data and the church investigation material and the affidavits to convince this researcher that the kernel of truth is present in most of the affidavits examined.

The affidavits were collected after the fact, in some cases long after the fact and tend toward the kinds of errors that all recollection of events and especially momentous events contain. Principally these errors seem to fall into the corrective vision area. By this I mean that the affiant tends to improve on his vantage point, correct his reporting of an event due to additional testimony and to strengthen or weaken his own advocacy in light of the facts as they later appeared to the affiant. Testimony taken in the depression years, by trade union activists, certainly is different than that which was offered in 1919.

Finally there is the strictly subjective evaluation of the affidavits. Do they have the ring of truth, or are they merely the fabrication of well intentioned partisans eager to protect those whom they believed to have been wronged? This answer is more difficult especially as we read the accounts of murder of Wesley Everest, a crime of terrifying violence. In the final analysis, however, I must conclude that the Centralia Affidavits constitute one of the central collections of reliable historical data dealing with the tragic and terrible event. 


\section{CHAPTER II}

\section{THE SETTING}

Centralia ${ }^{1}$ was founded by a uinque pioneer identified as George Washington Bush. Bush was a black man who had fled north to washington after Oregon had enacted restrictive "black laws" and forbidden the settlement of blacks in the state. Bush was a highly regarded neighbor and a trusted leader who, by settling in the Centralia area, attracted others who valued his judgment. Bush virtually gave the city away, seldom demanding more than a token payment for the land he owned. The surrounding forests provided ample building materials and employment for the first settlers.

The geographic location of Centralia, Washington is more advantageous. to the encouragement of commerce. It lies athwart the main transportation corridor leading from the Columbia River country to the south and the Puget Sound country to the north. Early traffic along this route and subsequent development of railroad connections between Portland, Oregon and Tacoma and Seattle led to the development of the town.- The two urban centers of Lewis county are Chehaljs, the county seat, and Centralia. The "twin" cities are six miles apart and duplicate

lGeorge Washington Bush, 1818 to 1872 , served as the founding father of Centralia. This former slave was responsible for the easy land acquisition policies of the first 10 years of the city's history. 
each other in services and advantages. Rail connections stretch west from the Chehalis-Centralia area toward the timber-rich Gray's Harbor region. The traffic south from Puget Sound ports made a stopover in Centralia waiting for transhipment to the "harbor." Finished lumber and timber products were shipped out through Centralia by rail so a lively and profitable traffic supported a wide variety of enterprise in the city. ${ }^{2}$

Centralia merchants had developed an extensive and profitable trade with the loggers who came to town from the camps on the weekends. City directories and newspaper ads indicate a large number of transient hotels, cigar shops, bars, restaurants, and drug stores, many of which prospered from their trade with the visiting loggers. Men heading to the "harbor" were forced to spend several hours in Centralia on their way to and from the logging camps. The American involvement in World War I saw a shifting of timber production resources south to the spruce forests of northwest Oregon.-- The Chehalis Valley forests- were cut over and their prime timber processed by the beginning of 1915. Centralia was no longer a loggers' town only; it was a saw mill town and a shipping center: Hundreds: of loggers-still filled the streets of the city on weekends, hundreds more passed through the train depot every day, but the residential work force, the "home guard," were sawmill hands and

2Lewis County, N.D. (Circa 1880) Published by Railroad promoters to encourage investment in the company. The entire bulletin is germain to the study in question as an impressionistic tool. 
semi-urbanized clerks, railroad workers, and odd-job holders. The loggers came into town from the camps on the weekends or between jobs. They were treated to the joys and sorrows of a small town Saturday night and bedded down in the clapboard hotels of Centralia's Tower Avenue.

The labor climate in Centralia was favorable. Railroad workers, clerks, butchers, carpenters and building tradesmen were organized and accepted as such by the Centralia business community. Working people served on a number of civic committees, boards, and commissions. Business relationships were:well established and most of the commercial establishments in the town were owned by local.citizens who depended on the trade and good will of the working people and loggers of the area. Centralia was not a "company town." Many lumber operations were headquartered in the city with none clearly dominating the life of the town. ${ }^{3}$

The life of the logger was dismal at best. He was bound for weeks on end in a primitive camp at the end of a fragile logging railroad, living in vermin-ridden bunk houses, forced to carry his bedding on his back to and from each job, and cursed: with a work day that of ten exceeded twelve hours. Food was-poor; wages slim and prospects slimmer. - It is no wonder that the logger was called the "timber beast." Efforts to organize the logger were met with suspicion and hostility by the lumber operators.

3Lewis and Pacific Counties Directory, 1914-15, 1915-16, 1916-17, R. L. Polk Company. 
Prior to 1917 loggers were almost impossible to organize effectively. The manpower shortage caused by national conscription for military service, coupled with the expanded demand for timber to support a mammoth effort to build wooden ships and the hundred of military cantonments springing up across America created ideal conditions for successful labor organization in the woods of the Pacific Northwest. Little attention had been paid to the logger as a potential union man. He had no craft in the sense that was understood by the American Federation of Labor. What Tittle organization existed in the woods was found among the railroad personnel and the operators of sawmill equipment. The only union willing to attempt serious organization of the "timber beast" was the Industrial Workers of the World. 4

As early as 1907 the IWW had been active in the Northwest. Originally interested in the manufacturing aspects of lumber, they were able to organize and initiate a partially successful strike of Mill Workers in Portland in the summer of 1907. Largely due to the Wobblies highly successful organization of Agricultural Workers in the wheat fields of eastern Oregon and Washington, a sizable number of eager and dedicated casual organizers spent their fall and spring season in the lumber camps recruiting new members. - This activity was almost startling in its effect. The Seattle Timber Workers organization grew from a handful of members until it became the largest component in the entire IWW. The Spokane free speech struggle in 1910 and the subsequent Aberdeen

4The Centralia Conspiracy, Chicago, 1920. 
and San Diego battles added additional impetus to the organization. Wobblies were imbued with an almost missionary-evangelical zeal in their clandestine efforts to organize in the woods.

The concentration of loggers made Centralia a prime site to attempt to reach the workers with IWW propaganda and hopefully to recruit membership. Early efforts were conducted by "walking delegates," those men who were armed with dues books, stamps, literature and a delegate's credentials and given the task of organizing the men wherever they were found. The procedure was simple. A man was engaged over a glass of beer, a lunch, a train depot waiting room and treated to a bit of IWW talk. The talk usually made up in gusto what it lacked in rationality, but the loggers were not interested in rational arguments, they were looking for a spokesman and the Wobblies promised to speak long, tough and loud. The walking delegate system (if we can identify it as such) grew out of the successful organization of the Agricultural Workers Industrial Union in the great basin country. A large number of the loggers were introduced to the IWW in the harvest gangs in the wheat country, where, as they put it, "they taught John farmer some manners!" The walking delegate was most effective working in a lumber camp where he could hold longer and more reasonable discussions concerning -IWW literature, ideas, and past activities with a virtually captive audience. Many men were radicalized on the edge of their bunks trying to read the Industrial Worker by the light of a flickering kerosene Tamp. 5

${ }^{5}$ See Vernon H. Jensen's Labor and Lumber, New York, 1945, and Carlton Parker's The Casual Laborer, New York, 1920, for details on this and other matters. 
As the spring logging season of 1917 opened, the IWW called a region-wide strike for an eight hour day, an end to the practice of bindling, and a general improvement in camp conditions. The strike was amazingly effective and after a two month period of resistance, employers, perhaps at the prodding of government officials, capitulated. The IWW demands were met and business proceeded.

The 1917 strike had been fought on the basis of patriotism as well as the economic issues involved. The Wobblies were quick to declare their opposition to the war which they regarded as another attempt of the ruling class to secure economic advantage in various world markets. As always with the IWW, their rhetoric was couched in the most violent and inflammatory terms. Regarded as little better than outright agents of the newly despised Kaiser, the IWW was viewed as a very real menace.

During World War I the federal government found it necessary to use -federa] troops to harvest timber in the Pacific Northwest. The Spruce Production Division was an attempt to return rational production to the timber producing regions of Washington and Oregon in order to insure a supply of spruce for the manufacture of vitally needed aircraft. The primary reason for this federal intervention was the successful organizing efforts of the Industrial Workers of the World which disrupted production. 6

6 Harold Hyman, Soldiers and Spruce, The Institute for Labor Relations offers an excellent overview of this period. University of California press, 1963. 
The lumber industry was responding to the tremendous demands for finished building stock as best it could in the face of wartime manpower demands. Many workers were enticed from the forest by the blandishments of the ship building boom in virtually every Northwest tidewater city and town. The shipyards were enjoying fat foreign and governmental contracts for both wooden and steel ships and needed a large pool of unskilled labor in order to meet their deadlines. This drain of manpower, when coupled with the steady filow of men leaving for the military, meant the heavily immigrant work force was a very unstable element in the profit projections of the lumber operators. The general condition was described by some unknown bunkhouse sociologist as the "Wobbly Horrors" and it accurately described the temper of the times.

The foundation of the Spruce Production division and the virtual impressment of thousands of Northwest timber workers into its ranks gave the federal government an opportunity to intervene in the already explosive situation. Colonel Brice Disque, hurriedly promoted to a general officer's rank and placed in command of the division, sought out the services of University of Washington sociologist Carlton Parker, who had investigated the IWW inspired Wheatland, California riot and asked for his recommendations on how to cope with what Disque perceived to be the menace of the IWW.

Parker's masterful-study The Casual Laborer attempted'with great success to identify the roots of worker discontent in the woods. Colonel Disque responded quickly by ordering the adoption of an eight hour day by all logging companies holding government contracts. By 
introduction of military discipline he was able to drastically improve the sanitary conditions in the camps and introduce a more humane and just system of governance. Disque felt that the IWW represented the enemy and that his job was to struggle as mightily against his enemy as Black Jack Pershing struggled with the Hun in the front line trenches. The form of Disque's attack on the IWW took several shapes. Federal intelligence officers conducted a series of Watergate style raids on wobbly offices, seizing membership lists, dues books, organizers' credentials, literature and paraphernalia. With these purloined bonafides they went among the loggers outside the spruce production division where the IWW still had a powerful sway and claimed to be "official union men from Seattle." When a favorable response was encountered, names were taken and a draft notice was dispatched in the next mail. Aliens were physically kidnapped and taken to the Canadian border where they were immediately inducted into the Canadian army, which was very casual about checking into a man's motivation for volunteering and even more casual about inducting a man into the military. Less fortunate were the Wobblies who were beaten into insensibility, fired from their-jobs; and left to combat a visible black list in the form of multiple cuts, bruises, and broken bones. The strongest possible effort was made to identify the IWW with the "hun." The IWW ideology constantly denigrated and "exposed" as virtually an active combatant against "the boys in the trenches." Disque spoke frequently of Americanism. This was clearly taken to mean docility, patriotism, and productivity. ${ }^{7}$

$$
{ }^{7} \text { Ibid. }
$$




\section{VIOLENCE ON TOWER AVENUE}

It was into this arena that the Industrial Workers of the World thrust themselves into in the spring of 1918. The success of the 1917 lumber strikes and the resultant impact of the implementation of the Spruce Production Division had caused a dislocation of membership. It was necessary to bring together the footloose timber workers who constituted the overwhelming part of the union membership. Toward this end, and with an eye to organizing the hundreds of unorganized workers who passed through Centralia on their way to "the Harbor," a modern and attractive hall was open in a good business district of Centralia. The mere presence of the headquarters was an affront to the business community.

In 1918 wartime nerves and patriotic zeal prompted the membership of several -local organizations to stage an impromptu-raid on the newly opened IWW hall. The raid was a spur of the moment event with little planning and no before-the-fact Jeadership. Normon Jobb gave an eye witness description of the raid to investigators.

The primafacie evidence of the existence of the Hall offers us enough to judge to dedication of the organization. Suffice it to say that without the necessary manpower the Hall need not have been operated. 
Jobb stated the following in his affidavit in 1936.

.. He had just finished his supper and was looking out the window toward Tower Avenue in expectation of seeking a parade which some of the business people in town had scheduled in celebration of some victory in France, or some Red Cross Drive or other. That he saw a contingent of said parade, the rear contingent as he remembers. it, branch off and proceed east on first street right in front of the affiants window. That said contingent stopped in front of the IWW hall, which was within the affiant's line of vision. The said contingent consisted of a very large group of persons, possibly: one hundred persons. That affiant saw said persons rush upon the IWW Hall. That he saw. them break in the windows and tear down the sign over the door, which sign as he:remembers it had been draped with the American Flag.

That affiant saw the raiders jumping up and down -in the street; that they were yelling and screaming like wild persons. That they screamed "lynch them, hang them, tar and feather them" That it was a scene of great violence and savagery.

Jobb also watched various businessmen hold an impromptu auction on behalf of the Red Cross disposing of the office desk and a victoria belonging to the IWW. ${ }^{2}$

This raid seems to have been a spontaneous event and was not marked by more than the destruction of furniture, some roughhousing and a good deal of patriotic oratory. In a somewhat more serious minded episode of violence Tom Lassiter, a blind news vendor, was abducted, beaten and told not to return to the city after he was seen selling the Industrial worker on the streets of the city. ${ }^{3}$

${ }^{2}$ Normon Jobb affjdavit taken in 1936 by Julia Goodman Bertram Ruuttilla..

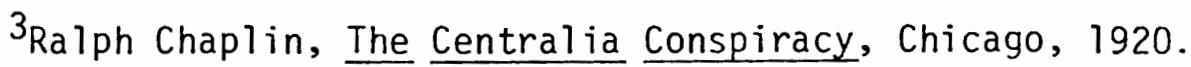


Business leaders reviewed the successful raid of the IWW hall during the Red Cross parade and questioned the local chief of police for expert advice. His answer that the Wobblies had a perfect right to conduct business in the city and that he could not legally interfere with their operations did not sit well with the assembled business leaders. Into this emotional breech sprang the commander of the newly formed Grant Hedge Post of the American Legion stating, "If you do drive them out of town there is no jury in this country that will convict you no matter what you do." 4

The end of the war did not lessen the anti-wobblie fervor of the local citizens. In June of 1919 local businessmen met at the Chamber of Commerce and after discussing stern warnings concerning the "hed Menace" formed themseives into a Citizens Protective League. The citizens League soon found a serious matter for their attentions when the IWW rented a modest office a few blocks away from the commercial center of town in an area that contained small hotels and bars which catered to the loggers. The Citizens Protective League began the custom of semi-secret meetings at the Elks Club to discuss the possibility of ridding the county of the IWW "at any cost. "5

While a pose of secrecy was maintained by the Citizens League word of the planning soon reached the IWW. A Mrs. McAlster, owner of the Roderick Hotel, in which the IWW had established their headquarters

${ }^{4}$ Ibid. Chaplin.

5John. M. McClelland Jr., "Terror on Tower Avenue," PNQ, April, 1966. 
sought out the chief of Police and asked for protection for herself and her guests. The secretary of the IWW, Britt Smath, made an unsuccessful attempt to discuss the rapidly deteriorating situation with the mayor. Finally, a handbill addressed to the people of Centralia was distributed by the Wobblies. This broadside asked the people of Centralia not to engage in acts of violence against the union and to prevent others from acting without recourse to the law. The handout only served to spread the knowledge of the proposed attack to every household in the city.

As a final step the Wobblies consulted Elmer Smith, a young attorney who had provided legal services for working class citizens in the community and who had shown an interest in the Industrial Workers of the World. After listening to the wobblies, Smith advised them of their right to defend their persons and property by force and violence if challenged. The scene was now set for a confrontation.

November 11,1919 was the first anniversary of the signing of the Armistice. The Centralia Chamber of Commerce visited the Grant Hodge Post of the American Legion and resolved to sponsor a parade through the city of Centralia by uniformed Legionnaires and patriotic organizations. William Scales, the post commander was heard to remark that the parade "would show them [the IWW] how strong we are."

The decision to include the newly organized Legionnaires in uniform was sponsored by members of the chamber who were the leaders of the Citizens Protective League. The newly returned soldiers, sailors 
and marines were still responsive to military discipline could be expected to present an impressive sight leading the line of march along Tower Avenue. The American Legion, organized initially in France by Army officers in the pay of the American Manufacturers' Association, had inducted virtually every returned serviceman with vague assertions that it would be through the agencies of the Legion that veterans benefits would be secured that the return to civilian life would be smoothed, and that the precious comradery of the trenches-woutd be preserved. The ranks of the Legion were full in the autumn of 1919. Due to the all-inclusive nature of the membership in the legion, the Grant Hodge Post included a sizable number of men who had a great deal more in common with the IWW than with the scions of Centralia's business and professional world.

The IWW of November 1919 was not the same union that boldly entered the Everett waterfront. singing "hold the Fort." In the three years since the episode in Everett the union had experienced the most bitter attack ever visited on a labor organization in America. Virtually every office of government from the highest courts and legislature in the land through the most humble city council had acted in some way to restrict the IWW. Criminal Syndicalism laws were being enacted-across the Northwest in cities and by state. legislatures. Between. May and the end of October over 70 IWW were arrested and: tried under the new-Crimina- Syndicalism laws. Almost invariably they were acquited, George F. Vanderveer, chief attorney for the Northwest General Defense fund of the union was kept 
in an almost constant state of motion through Washington, Oregon, Idaho, Montana and Nevada setting up defenses for the embattled union members. Enormous financial drain was being made on the meager resources of the union. 6

The Wobblies were truly on the defensive and this time not as the agrieved champions of the downtrodden worker but as the agents of the Kaiser, recently defeated on the battlefield but newly revived in the personage of the leadership of the Russian revolution.

The IWW was bereft of national leadership at this time as well. The Chicago headquarters group was under arrest and lodged in the infamous cook County Jail. The files and records of the union were seized and every effort was made to disorganize and intimidate the membership. Organization in the woods was proceeding but at a much slower pace. The government sponsored Spruce Production Division and its vicious undercover attack on the IWW had made it difficult to attract and hold membership at the 1917 high figure. Membership turnover was high, representing about $80 \%$ of the union at times. The makeup of the work force was changing as well, more and more men were beginning to settle down in the small towns which were springing up around, the logging camps and mill sites. The wobblies spoke- contemptuously of the "homeguards" and failed to analyze the changes that the wartime prosperity had wrought in their industry.

${ }^{6}$ Counsel for the Damned, Lowell S. Hawley and Ralph B. Potts, Philadelphia, 1953. 
More and more the union was being aggressively challenged by industrial and civic groups ready to apply the lessons learned at Aberdeen, Bisby, Everett and Butte. More and more the union organization fell into disarray due to governmental rajds, the arrest and harassment of local leadership, deportation and physical intimidation. In early October a wave of hastily called and poorly planned strikes were called in the "short $\log$ " or pine forest regions of eastern Oregon and Idaho. These strikes had as one of their demands the release of the class war prisoners being held in the jails of America. ${ }^{7}$

In Centralia the IWW was making plans for the defense of the union hall. On Monday, November 10, Britt Smith canvassed the members of the union then in Centralia and asked them if they had weapons and would be willing to occupy the union hall during the hours immediately before and during the parade. Since several of the IWW's had rooms in the Roderick Hotel which housed the hall they were, in effect, drafted by their proximity to the center of the action. Several other men had rooms in the neighboring hotels but were willing to come to the hall during the parade. Two men were asked to station themselves on a low ridge called Seminary Hill where they were to provide supporting fire if the situation at the hall developed violently. Affidavits secured by labor investigators in the late 1920s and the 1930s indicate that the planning concluded by the IWW before the raid on the hall was sketchy

7Melvyn Dubofsky, We Shall Be All, Quadrangle Books, Chicago, 1965. 
and based on the notion that while a confrontation might occur that arrest was far more likely than battle. During this period of time the Citizens Protective League was not idle. They met secretly at the rooms of the Elks Lodge in downtown Centralia to discuss the situation after the official lodge meeting concluded. The affidavit of D. E. Burre $11^{8}$ offers us an account of what happened at the 0ctober. 20 meeting held at the Elks Lodge. The affidavit speaks for itself and illustrates the richness of detail found in the earlier affidavits, this taken in early 1923.

D. E. Burrel], being under first sworn under oath, states: that on October 20, 1919, and prior thereto he was employed by the Lincoln Creek Lumber Company at Galvans, Washington, $4 \frac{1}{2}$ miles from Centralia. That on said day he was requested by one Bob DeHaven mill foreman of said company to attend a meeting to be held at the Elks Lodge Room at Centralia, Washington. That he proceeded to town, and entered said lodge room. That approximately 125 people were present at the said meeting. That the meeting was held under the auspices, so he was informed by the chairman, of the Citizens Protective League. That the object and purpose of said meeting was to devise ways and means of ousting the Industrial Workers of the World from the said town of Centralia, That one of the city commissioners of said city got up and said, in substance, that he had no authority, and there was no law on the Statute Books of the State of Washington, to revoke the license of one McAllister (of Roderick Hotel) the owner of the building; where the said organization was conducting its meetings, and which owner was at that time conducting a rooming.house... . That the chief of police of said city verified this statement and further added that he was informed by the ci.ty and county attorneys that there was no law to stop the I.W.W.S from holding forth in the streets of the city of Centralia.

That following these statements,.. a person, unknown to affiant, got up and said the only way to-handle the I.W.W.'s in Centralia is to do the same thing we did in Aberdeen, 'Clean 'em up, and burn 'em out' This met with general approval. A committee was appointed to rid the I.W.W.'s which consisted in part of Warren 0 . Grimm, as Chairman, one William Scales and F. B. Hubbard.

${ }^{8}$ D. E. Burrell affidavit taken by Elmer Smith in 1923. 
That on November 11, 1919, in the fornoon, affiant met Arthur MCElfresh, and said MCElfresh informed affiant that 'they have decided to raid the I.W.W. hall after parade.' That a parade was scheduled that day. That the said McElfresh made the above statement in a manner which indicated disapproval. That affiant knowing that one Elmer Smith was the attorney for said organization went to the office of said Smith and so informed of the above statement. Affiant had no interest in the said organization, he was not connected in any manner with it, but was at that time a delegate to the Central Labor Council.

That shortly before the parade got underway on the said November 11, 1919, he saw one of the paraders dressed in a uniform and carrying a gun. Asking him what the gun was for, the individual replied, 'I am goin to give it to Burt.' or 'I got it for Burt.'

That not long after the parade got underway he saw the glass broken in the door of the hall of the I.W.W. by the paraders, and then heard the shots of guns.

That after the turmoil was over he asked one of the paraders in a group, people he know had come over from Chehalis, who were dressed in uniforms, what the trouble was, and he was informed that 3 men had been killed. The same person continued by stating, 'this is a 'helefer' thing to bring us up here for. We expected to have a good time.'. . .

Paul.S. Stackhouse recalled this same meeting in his 1936 affidavit for the Free Ray Becker committee. ${ }^{9}$

. . . in the year 1919, affiant was a member in good standing of the Elks Lodge in Centralia. That on or about October 20, 1919 he. attended-a regular meeting of the Elks in their club house on Pearl and. Locust Streets in Centralia, Washington. That approximately eighty persons attended this meeting.

That after the regular order of business had been disposed of, the meeting mentioned above was turned over to F. B. Hubbard, who made a talk on ways and means to rid the town of Centralia, Washington, of the I.W.W. That the said F. B. Hubbard advocated running the I.W.W. members out of Centralia by force, if necessary...

That it was decided to form an association or committee to deal with the subject mentioned above. " That the name of-this association was to be the Citizens Protective Association.

${ }^{9}$ Paul E. Stackhouse affidavit taken in 1936. 
The secret group was becoming a public group, the plan to attack the IWW was beginning to take form in the minds of Centralia's citizens under the leadership of Tumber operator F. B. Hubbard.

The message of aggressive action was carried to the membership of the Grant Hodge Post of the American Legion during an informal meeting on the evening of November 10, 1919. Reports of planned violence against the I.W.W. were already in common currency throughout the cjty. Claude Clifford, a young coal miner attended this informal meeting and gave this account in his affidavit.

. . on the same evening (Nov. 10, 1919) there was a meeting of the Centralia Post of the American Legion at the Amory in Centralia, and that I did attend this Legion meeting; that this latter meeting was called by Dr. David Livingstone, Hank Andrews, George Forsyth, Dick Wyatt, two Roberts brothers, whose given names I cannot not recall, and by a number of other persons, and that personal friends invited me to attend.

This meeting was dominated and controlled entirely by the following persons, who seemed to do all the talking: George Forsyth, Dick Wyatt and Dr. Livingstone, they gave instructions to those present that they should form themselves within the ranks of the 9lst Division in the parade to be held the next day, whether they ac.tually belonged with said 91 st Division or not; all the persons were instructed to parade up to the front of the I.W.W. Hall on Tower Avenue, when and where they sould break ranks and attack the I.W.W. Hall and demolish it; with respect to possible opposition from the occupants of the hall, the instructions were 'to take them as they come.'

November 11,1919 was a typical fall day, overcast, cool and to all unpieasant. . The town of Centralia was excited about the first celebration of Armistice Day and the parade that was to be held to commemorate the occasion. 
The route of the parade was one which had been used for several years. It formed at the City Park near the center of town shortly before 2:00 p.m. The parade was composed of several more or less independent units, the first comprised of members of the popular local Elks Lodge, the second unit a marching band from the high school, the third contingent was from the Boy Scouts joined by a sprinkling of Marines and sailors, fourth in the line of march were members of the Chehalis American Legion Post, fifth in order were the members of the Grant Hodge Post of the American Legion arranged by unit of service, they constituted the largest component of the parade. They were followed by the final unit, several automobiles containing Red Cross Nurses in uniform. The Grant Hodge unit was led by Lt. Adrian Fredrick Cormier on horseback. Cormier had served as a "wig-wag" signals instructor in the cavalry and had never left American shores.

Remaining in this order the parade moved east on Main Street to Pearl Avenue then onto Tower Avenue moving north along the left side of Tower where it intersected Third Street." At this point similarity with previous parades stopped. Rather than following the usual procedure of turning around a-block or making a " $U$ " turn in the street the marching units stopped, marking time in the street. Most of the units continued along the route of march retracing. their.steps along Tower Avenue. Each unit seemed to hesitate briefly executing the turn causing gaps to form in the parade as is often the case in such celebrations. The military units executed smart "about face" maneuvers and continued to mark time. 
The Chehalis contingent stepped off opening a gap between it and the Centralia legionnaires who were now positioned immediately in front of the I.W.W. Hall in the Roderick Hotel. ${ }^{10}$

In 1924 Elmer Smith, the young attorney whose role is central in the events of that November afternoon, took the affidavit of A. L. Bond, a young timber worker who witnessed the raid. 11

That on said day, November 11, 1919, this affiant was in Centralia, in the afternoon to get a load of machinery for the Napavine Lumber Company, and on or about two o'clock of said day this affiant was in the north-end of Centralia on the east side of Second-Street, near Tower-Avenue, Centralia, Washington, near the hall of the Industrial Workers of the World. That shortly thereafter the Armistice Day parade came along and blocked Tower Avenue, so that affiant could not get through with his truck. That the parade went on by Second Street to Third street and they turned back on Tower Avenue. That in the rear of the parade was 100 or more ex-service men in uniform. That the ex-service men were in two divisions or groups and this affiant afterwards discovered that the first group was Chehalis ex-service men and the last group Centralia ex-service men. That the Chehalis ex-service men went by Second Street... That thereafter a man on Horseback blew a whistle and this stopped the rear group of ex-service men in front of the hall of the Industrial Workers, between Second and Third Street, leaving a break in the parade between the two groups of ex-service men of almost a block. That he heard a number of calls and orders but could not make the same out. That on at least one occasion before the actual raid men broke ranks of the parade and started for the hall but came back, apparently receiving the wrong signal. That finally a group of several men broke ranks, rushed the hall of the Industrial Workers, smashed the glass front of the hall and smashed in the door and at least one man-actually entered the hall before any shots were

${ }^{10}$ Chaplin, Campman-and Federal-Report plus virtually-every other investigator agree on the details of the event up to the raid on the hall.

${ }^{11}$ A. L. Bond Affidavit taken in 1923 by Elmer Smith. 
fired. That immediately following this raid a number of shots came and shooting only lasted a second. That immediately thereafter this affiant saw two wounded men fall and stagger back from the hall.

Another 1924 affidavit offers this account of the attack on the 12

Industrial Workers of the World Hall. Allen Maynard was a student

at Centralia High School in 1919, he subsequently served in the United

States Navy for three years. He remembered events in the form.

On iNovember $11,-1919$ we were given a half-holiday at school, and I went over to Tower Avenue to watch the Armistice Day parade. I followed the procession from Main Street northward to the Avalon Hotel, which was on the East side of. Tower Avenue a short distance south of Second street. In front of the Avalon I met my friend Bob Gavin, who was rooming at that hotel, and I stopped to talk with him.

While standing there with Gavin, I saw the paraders go to Third Street, turn and come back. The Chehal is bunch was in the lead of the soldiers; being followed by the Centralia bunch. One of the Centralia ex-service men, about 30 years old, carried a small coil of rope, about half-inch in diameter. There were about four or five strands of this rope, and I imagine it would have stretched 12 or 15 feet.

The Chelas bunch marched southward past Second Street, but the Centralia bunch halted in front of the I.W.W. hall. Shortly after they halted I heard the sound of a whistle. Then somebody yelled something I couldn't make out, then some of the Centralia soldiers left the lines and rushed the hall.

It was after this that shots were fired, a good many of them, somewhere near the hall. I heard no shots fired from the vicinity of the Avalon Hotel. My hearing has always been good. There was a good deal of confusion while the shooting was in progress, people running. in various directions, and much shouting.

Several seconds after the shooting began $I$ saw Lt. Warren Grimm coming from the direction of the I.W.W. Hall. He was about. 25 feet north of the corner of the Co-operative store, and he was holding his gtomach as if he were suffering great-pain.- He came southward staggering; and turned westward-into Second Street. I had known Grimm for a long time.

${ }^{12}$ Allen Maynard Affidavit taken by Elmer Smith in 1924. 
Cecil H. Draper was cited for bravery under fire and was a participant in the battles at St. Mihiel, Flanders and along the Meuse-Argonne front. ${ }^{13}$ His affidavit given in 1924 reports a conversation he had with a close friend, Eldon Roberts, a wounded veteran and dentist who marched with the Grant Hodge Post.

Roberts described his part in the affair subsequently as follows:

When the Centralia Division got in front of the Wobbly hall, he said, we were halted. McElfresh started for the hall with a message. When he got half-way to the hall somebody yelled: 'Let's go!' The fellows broke ranks then and started for the hall. I ran toward it, and reached the doorway about the same time as McElfresh. He and I pushed against the door and got it open about three inches. I looked through the opening and saw a bunch of men lined up with guns inside. They started to shoot. At first I thought they were fooling and trying to scare us. Then I looked at the panels on each side of the door, and could see where the bullets were coming through. I realized that the Wobblies were in earnest and I got out of there. I ran to the corner of the One-Cent One-Dollar Store, and was just turning there when McElfresh fell into my arms.

B. A. Heath came to Centralia to buy some cigars because it was his birthday on November $11 .^{14}$ Caught up in the spirit of the event he paced the Centralia unit which contained many life long friends and acquaintances while striding along the sidewalk. He was immediately opposite the I.W.W. Hall. A boyhood chum of Arthur McElfresh he was aghast when the young shopkeeper fell in the first seconds of the shooting. He recalled those violent moments in his 1936 affidavit.

13Cecil H. Draper Affidavit taken by Elmer Smith in 1924.

14B. A. Heath Affidavit taken by Elmer Smith in 1924. 
- After the door of the hall had been pushed in, affiant heard a shot ring out. He does not know who fired this shot. He saw Arthur McElfresh standing just inside the doorway of the I.W.W. Hall; he saw him fall backward and practically out of said doorway. After the first shot and almost simultaneously with it, more shots rang out. Affiant saw Warren Grimm standing in front of the door, sort of doubling over and clutching his side and stomach as if in pain. . . He saw George Barner and others lift McElfresh out of the doorway and lay him on the sidewalk, along side the building. Affiant said 'What the hell is going on here?'

Bernard M. Eubanks won the Croix-de-Guerre on the battlefields of Belgium where he fell wounded in battle. After recuperation he rejoined his unit and fought in several hotly contested campaigns. His affidavit is unique in that he was an active Legion member although by the time researchers had found him working in his Salem Upholstry Shop he had quit the organization and denied all prior knowledge of the raid. In his key affidavit he admitted to falsely testifying under threats of reprisal at the trial of the IWW members.

Owing to the long lapse of time, I am unable to recall my exact position in the parade and so cannot state positively whether I was in the first or second contingent. When the parade halted on. the return trip, I was a little way south of the I.W.W. Hall and perhaps fifty feet from the Second Street intersection. I believe I was on the far side of the column. At the time, I gave no thought to the reason for the halt nor did I remark that in marching north, we had gone several blocks beyond the usual line of march of parades in Centralia.- The unusualness of such procedures-occured to me later.

When the column had been halted a short time, I heard a.commotion in the ranks behind me. The commotion was caused by a scuffling of feet and by shouting. I heard someone call out "Go get them!" I turned around and saw some of the fellows running toward the I.W.W. Hall. Shortly after this, I noticed someone in front of me and at the east side of the column, break ranks and run toward the ha11. I am now unable to remember. whether the last mentioned incident occured before or after the shooting but I can state positively that the ranks behind me were broken before there was shooting. 
After the shooting started, everyone near me ran for cover. I myself ran toward the west side of Tower Avenue. When I was midway of the street and perhaps a little north of the Second Street intersection, a bullet struck me in the calf of the leg. I realized and knew at the time that I had been shot. . . .

MCElfresh and Grimm were not the only legionnaire fatalities of the day, a young Greek immigrant was killed in the street outside the ha11. Ben Cassagranda, called a bootblack by some and an "eager young go-getter" by others, was newly married and had high hopes of making his way in his adopted 1and. ${ }^{15}$ Most of the wounds received that afternoon -.....were minor, many the result of a .22 fired at long range from Seminary Hill more than $1 / 4$ mile from the hall. The amount of time taken to complete the bloody business was literally seconds, the aftermath would drag on throughout the day into the evening and then in the courts and prisons of Washington State for 20 years. The event John McClelland has called "The Terror of Tower Avenue" might more properly be identified as the tragedy of Tower Avenue.

${ }^{15}$ Florence Cassagranda. Mahar Affidavit taken by Elmer Smith in 1924. 
CHAPTER FOUR

\section{REACTION}

After the shooting on Tower Avenue stopped and those dead and wounded were offered what succor available, a kind of shocked amazement gave way to a frenzy of activity. A group of legionnaires dragged the men captured in the hall away toward the city jail. Other's clustered around the now destroyed hall viewing the scene of death. One viewer described the scene as follows:

The red stains were still on the sidewalk, all the way from Second Street to the Hall. J. C. McAllister, one of the owners of the building in which the hall was located was in the doorway. With his permission I entered the hall and looked around. I observed red stains on the floor, these stains forming a continuous trail in connection with those on the door step and on the sidewalk. There were red splotchs on the floor a distance of seven or eight feet back from the doorway.

In addition to the blood stains, the interior of the hall was destroyed. Chairs, tables and other furniture were completely smashed. Literature was torn and scattered everywhere. Bullet holes dotted the door which lay smashed and ripped from its hinges.

A new mob was forming itself around the city jail, arming itself with weapons seized with the cooperation of local officiats of the state militia from stores kept in Centralia. A constant shouting and

${ }^{7}$ Thomas Duffy Affidavit taken by Elmer Smith, April, 1925. 
yelling at the men jailed inside plus the coming and going of deputies hauling in suspected IWW members and sympathizers, and a steadily growing number of idle watchers characterized active during the 30 minutes immediately after the shooting. 2

The men in the hall quickly attempted to hide in the hall. A large walk-in refrigerator offered temporary shelter to several. One man bolted out the back door of the hall clasping a .4 .5 automatic in his hand. : He ran through several yards and along the streets pursued by an increasingly large mob. At the forefront of this mob were several ... Legionnaires who had armed themselves either with weapons handed to them by citizens or with guns carried secretly in the parade.

Wesley Everest was the son of pioneer-Oregon settlers, he had served in the Spruce Production Division and was honorably discharged. Everest had been an early. convert to industrial unionism and the IWW having taken part in an abortive effort to organize lumber workers in the Coos Bay-Marshfield area during 1915. . He had been forcibly deported from that area, beaten and made to hike 30 miles up the beach to the next town. ${ }^{3}$ By 1919 he was. a dedicated revolutionary who had made $=a$ name for himself in radical and labor circles in Portland where he was a close associate of Dr. Marie Equi, the reigning radical woman of the hour and a-strong I.W.W. partisan.

${ }^{2}$ Calude Clifford Affidavit taken by Irwin Goodman in 1932.

3 Marshfield Sun, March 14, 1915. 
Everest's run had been punctuated by stops when he turned to fire a shot from his automatic at the mob which was hot on his heels. These interruptions kept his pursurers at a respectful distance. Everest ran on until he reached the banks of the Skookumchuck River, a stream about 40 feet wide and running very deep due to the fall rains. Everest waded into the river to about chest height, hesitated and began to retreat to the shore. It was later revealed that he could not swim. By this time the pursuing mob had caught up to him and was lining the bank. Everest. menaced them back with the automatic and stepped closer to the shore intending apparently. to continue his flight on dry land. One of the mob did not retreat, Everest fired several shots emptying his weapon, he then threw the automatic at the crowd. The shots killed Dale Hubbard, nephew of E. H. Hubbard, the Targest Jumber operator headquartered in Centralia and a sworn enemy of the IWW. Everest refused to surrender save to an officer- of the law. He was. overpowered quickly and beaten-by the enraged mob. $\therefore$ A military belt was placed-around his.: neck .and his arms were bound, the mob began its return to town. ${ }^{4}$

Here is how Glen LeBaron, an eye witness to the events that followed described the scene to researchers in 1936.5

Perhaps thirty minutes afterward =he-noticed a crowd: of citizens and persons in soldier!'s uniforms coming down the middie: of-Tower Avenue headed south and he joined the crowd in front of the-Pass Time Pool Hall:and soon saw a group of. soldiers leading Wesley : =. Everes.t by a soldier's belt kinched up and around Everest'-s-neck. The crowd about Everest was hysterical Both men and women were kicking at and spitting at the prisoner and screaming. In his

4Percy Draper Affidavit taken by J.G.B.R. in 1936.

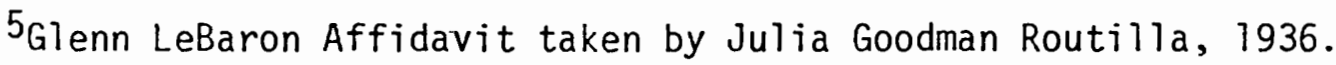


opinion Everest would have been mutilated or killed then and there except for the fact that members of the crazed crowd got in each other's way in their attempts to injure Everest. Everest was then led to the alley that bounded the city jail on the East and was placed under an electric light pole at the rear of the Farmer and Merchants Bank, where a hangman's noose was suspended about 6 $\frac{1}{2}$ feet from the ground from a cross arm on said pole. Everest was led beneath this noose. At this time his face was bruised and he had been badly beaten. Affiant stood about 10 feet from Everest. There were a great number of firearms distributed among the crowd there assembled. Everest called the crowd names, cursed its members and defied them to slip the noose over his head. He called them 'Cowards, rats and Hubbard's hirelings.' No one seemed to have courage to slip the noose. After several minutes of turmoil a Mrs. William Bray, whose present address is 873 Middle Street, Chehalis, Washington, an elderly lady, and one of her daughters stepped to Everest.'s side and begged the soldiers not to molest him further. In the Affiant's opinion only a woman could have done this and lived at that time. Then one William Scales and one James Churchill moved in close to Everest and begged mercy for him. Immediately thereafter a man in uniform named Guy Stevens, who is the present proprietor of Stephen's Cleaners, West Main Street, Centralia, stepped up and called. Everest names and thrust. a muzzle of an army rifle into Everest's front teeth. Everest's face was then a bloody pulp. Another man in uniform immediately grapsed a revolver by the muzzle and struck Everest on the head just back of the left eye with the butt of said revolver. Everest seemed to waiver in a semi-conscious condition for a moment and then go unconscious. Animal like groans and moans came from him.

Everest was dragged into the jail building and placed in the corridor of the cell block immediately in front of the cell containing those apprehended at the time of the raid. The sight of Everest's beaten and battered body particularly unnerved young Loren Roberts and Tom Moore. - James McInerny;-a veteran of the Everett-Massacre-and the jailing and court case that followed shouted repeatedly to those held in near by cells. "don't tell them a thing, don't tell them a thing!" 6

6alph Chaplin, Centralia Conspiracy, Chicago, 1920. 
The jail was packed with police officers, sheriff personnel, legionnaires and men grabbed off the street either as un-deputized possee men or as suspicious characters, this category was filled almost 100 percent by men wearing the garb of loggers. As the minutes passed more men brought additional prisoners to the jail,-.one was young Dewey Lamb who was arrested at his home together with his father John Lamb who had been placed upstairs in the Arnold Hotel with 0. C. "Commodore" Bland. John Lamb had fled to his home at 1428 Kulien Avenue in the confusion after the rush on the hal1. Dewey Lamb recalled the events of that afternoon in.1936 to a representative of the Free Ray Becker Committee. .

. . on November 17, 1919, I was made a prisoner by a mob numbering some 150 soldiers, sailors, high school boys and Centralia businessmen. These gangster's came $\because \therefore$. about $2: 30$ in the afternoon. They were informed by one Bud Hansen that my parents, sisters and myself were across the street at the home of a neighbor, Mrs. Claude Borne. The mob surrounded the said Borne house and demanded that my father and I surrender- to -it.: Upon our refusal to do so.,.. we were ordered to put up.our hands at. the points of guns. Many of these guns were cocked and trained upon us by inexperienced and. shaky hands. = I was grabbed by three big, strong fellows, all wearing the uniform of the U. S. Navy and pushed into a car. In the car, I was handled roughiy, sworn at, and asked many questions pertaining to matters of which I had no knowledge. When I could not answer said questions, I was prodded with guns and told: 'You s-- of a b--.-, you do know, you better tell everything.

When we came to the jail, I was taken out of the car and held at the jail door by two sailors while the: third took a run of ten yards and gave me a : kick which rendered me unconscious.- When I. . came to, I was 7 ying: on the floor of the jail, very $i 17$ from the effects of the kick......

Upon my father's arrival, I was locked with him in the- ladies cell. or women's quarters. where the mob could see us through the 
open, barred windows. Members of the mob pushed rope through the window and told us as soon as it got dark they would take us out and stretch our necks.?

(During this period of utter confusion and chaos rumor has it that one man was beaten to death in a cell in an attempt to gain information. His body was al-7egedly removed from the jail later that same night and burned in the incinerator of a lumber mill. I have found no corroboration of this story in any published account or in: the affidavits.) $)^{8}$

Elsewhere in the city other more purposeful: men: met: to:plan for the evening's action. Claude Clifford, a young coal miner, a partisan of the Grant Hodge Post of the American Legion and a loyal-member of the Benevolent and Protective Order of the Elks described what happened next.

About $4: 30$ or: $5: 00$ p.m. on the said day of November, 1919, I was at the Elks club in Centralia in attendance upon a meeting presided over by William-Scales,-when four men were appointed to go to the armory and get:guns and ammunition; at this meeting William Scales challenged. my right to be present, .. asking - if I were an overseas man, and if I belonged to the Legion. I replied that $I$ : was not a member of the Legion and Scales then accused me of : holding a !'Red Card. ". Scales said that, knowing my-family; he was surprised at such conduct, but. I defied.him to throw me out. and I was allowed to remain.

I went to the Armory with the committee and took two guns, - a Colt . 45 and a . 30 Craig krag Jorgenson from the officer in charge of -the armory, going from there to the Elks Temple. - The instructions which I had been given were to report to the Temple at 6:00 p.m. and at that_time a meeting took place: called by Dick Wyatt, Dr. David:Livingstone, C. . D. Cunningham, Harry-Moore; : Art Robinson, George: Forsyth; and some others-whose $=$ names id do not . ..

7Dewey Lamb Affidavit taken by Julia Goodman B. Ruutilla.

8Interview by Eugene Nelson, IWW official 1971 and heresay material-gathered-b.y.Julia Goodman B. Ruutilla in 1936. 
recal1. Dr. Livingstone opened the meeting and Dick Wyatt stood on a desk and said anyone in the house who did not belong to the Elks or the Legion should get out for 'We are going to hand [hang? this bunch of rats?' Up to this time about 75 persons were present, but quite a number left, leaving perhaps 30 or 40 there; about this time I left the hall. ${ }^{9}$

Charley Eagles was concerned about a friend who had the ill fortune to find himself in the Centralia-Jail at the same time the IWW were being rounded up. In no way connected to the IWW, Charley's friend probably offered a good excuse to get inside the jail which Charley Eagles was abie to do, due to his close friendship with chief of police Hughes and his duputy, Claude Carter. In June of-1936,: Eagles recalled the events of the early evening of November 11 .

. . While he was in the jail, affiant saw a man lying on the floor of the corridor, that this man was twisting about in agony and bleeding like a stuck hog. That bjood was coming from the said man's mouth, ears, and nose and he-was a-pitiable sight.

That after affiant had finished his business in jail, he stood just outside the door, leaning against the door casing, together with one of the deputies, Claude Carter.-- That on the other side of the door (also-outside building;-of which said door had been locked) were Chief of Police-Hughes and Mayor Rogers. That Sheriff:-Berry -was: close by:- That all of: these persons-were well know to the affiant. That a- large crowd, possibly two hundred persons, had gathered near the jail; that these. persons stood in the s.treet and across the street. That Chief of Police Hughes was keeping the crowd away from the door of the jail so that there was a large clear space from the said jail door to the street. That affiant said,..'There's going to be trouble here, what is going to happen?', or words to that effect. . Chief Hughes said there- was nothing he could do.

That minutes before the jait was broken into, the lights of the city went out. - That a car with lights on came up and a $\mathrm{Mr}$. Churchitol-of the Gilove works ran up and kicked out the lights :.....

${ }^{9}$ Claude Clifford Affidavit taken by J.G.B.R. in 1936. 
That affiant saw a group of men come up to the door of the jail, that some wore masks over their faces, that they carried a smallsized 25 foot telephone pole. That as nearly as the affiant can remember, 5 to 7 men had hold of this ram. That E. Gurlichs, the druggist, Frank Van Gilder and David Livingstone were with them and.directed them in what they did. That they tapped on the jail door a couple of times with said ram but not hard enough to break in the door. That the said door was then unlocked from within by Officer Jackson; that the affiant got a good look at Jackson before he (Jackson) stepped behind the door as he opened it. That 3 or 4 of the above group went into the jail...10

Shortly before the City lights were extinguished young Dewey

Lamb was led from his cell in the women's detention area.

- . I was taken out of my cell-for questioning. About this time the lights went out. As members of the mob came thru the jail door, someone turned a flashlight on. I saw R. B. Hubbard; he was the first man to set foot across the threshold. He screamed 'Turn out the light; some IWW son of a bitch might see our faces.' I heard the mobsters say they were after the secretary. Wesley Everest =was lying on the floor of the corridor, bleedingprofusely. (A stream of blood had run from his mouth to the door of the jail office ten or twelve feet away.) When the mobsters came up to him he got up and tried to fight but was weak from loss of blood and was almost at once overpowered. I was pushed under a desk and hidden away from the mobsters. I heard a police official say it might be a mistake to lynch a kid as young as I was. 11

The young coal miner, Claude. Clifford continues his narrative at this point.

Not knowing into which car Everest had been thrown, I jumped into the front seat of said taxi. Everest most of the time was on the floor of the rear part of the taxi. Besides Borgard (the taxi owner), Everest and myself, the following persons were in the taxi and were in the back seat thereof: Dr. David Livingstone, Dick Wyatt, :George-Forsyth, : and a man who was manager of the Liberty Theater in Centra]ja.=- During the raid on the jail C. D. Cunningham took charge of the raid and shouted directions to the raiders.

${ }^{10}$ Charley Eagles Affidavit taken by J.G.B.R. in 1936 .

$1 l_{\text {Lamb Affidavit, op. cit. }}$ 
I jumped into the taxi out of curiosity, not knowing that Everest was in it; it was in a line of cars headed for the Chehalis River bridge. Just after the cab crossed the railroad tracks, Everest hollered and screamed and at the bridge he was taken to the front of the car to get a full view of him. The front of his clothes had been torn off and his.privates had been cut off; Dr. David Livingstone had said privates in his hand and laughingly said he would pickle them in a jar; Dr. David Livingstone's hands were bloody and I saw he had his doctor's instrument case with him. Thereafter, at the bridge, Dick Wyatt, C. D. Cunningham, Dr. David Livingstone and a small man who runs a clothing store in Chehalis, and whose name I cannot recall, seemed to be the moving parties among a large throng. They threw a rope over Everest's neck and suspended him from the bridge, but there was only about six feet of rope and it was not long enough to snap Everest's neck. However, the drop tore the flesh loose from around his. shoulders. The same group then pulled him up and Everest- said, 'Why don't-you kill me like a man. I have fought for your country and for you guys, so why don't you treat me like a man and shoot me?'

Shouts that 'We'll fix you,' and other similar expressions were made by many persons in the crowd. I estimate that more than 100 persons were present. Everest was then hung on about 30 feet of rope but still his neck did not seem to be snapped. Flashlights were shone upon him, and a lot of shooting started, this being led by the small man from Chehalis who has the clothing store there. I should estimate that 25 or more bullets were shot at Everest at this time. 12

Wesley Everest died in that hail of gun fire suspended above the Cheha] is. River. lit by the headlights of the cars that had carried him and his lynchers to the site. The towns people were curious about the activities of the evening. Soon word spread that the mutilated body of Wesley Everest-was swinging in the wind from the Chehalis River bridge. Car caravans drove to: the lunching grounds where spectators gawked and a few. of the bolder bravos fired meaningless shots into the lifeless corpse. ${ }^{13}$

12Clifford Affidavit, op. cit.

13 Ibid. 
The next morning the body was retrieved and returned to the Police Jail where it was placed in a cell immediately adjacent to the IWW prisoners. The day and evening of abject terror was punctuated by the sudden and hidious presence of the Everest corpse. The aTready unsteady Loren Roberts lapsed into a state of dementia from which he was not to recover for almost six years. The shock effect was an enormousiy terrifying event in the life of young Tom Morgan, destined to turn states evidence in the- face of threats that he would meet a:. similar doom.: Years later he was to recant his confession and tell of his feelings while staring at the mutilated body of his "fellow worker." The affidavit of Tom Morgan was particularly difficult to obtain as the young man had left the northwest and hidden himself in the mountainous country around Arcata, California. He spoke frequently of risking his life by signing the statement and said that he was being watched.

Sometime the next day, the body of the said Everest-was placed in the cell directly across the corridor from that of the affiant. The affiant knew the said Everest had been 7ynched and this knowledge and the signts described made a deep impression on affiant's mind.

A final act had to be completed to finish the matter of Wesley Everest, the body had to be disposed of after it had served its purpose of intimidation and terror.-Simon Hill, one of the arrested suspected IWW sympathizers : told investigators of his part in the-final pages in: : :the life and death of Wesley Everest.

14Tom Morgan Affidavit taken by J.G.B.R. in 1936. 
. . . the battered and mutilated body of Wesley Everest, with clothes torn from his body was thrown into an adjoining cell in the plain view and presence of this affiant and other prisoners; that the body of said Wesley Everest remained in the said jail for more than forty-eight hours to the knowledge of this affiant and thereafter, this affiant and three other prisoners were called out of said 'Bull Pen' and taken back of said city jail where this affiant saw them throw the body of Wesley Everest into a rough board box. . 15

After a difficulty with a driver who refused to carry wobblies was solved by his replacement with one less fastidious about his cargo, Simon $\mathrm{Hill}$ and three companions were placed in a closed truck under an army guard complete with fixed bayonets and driven for about a half hour to a chosen cemetary. They buried the coffin in an unmarked grave under the taunts and threats of their military guard. An anonymous photographer captured their image while at their morbid task. They were remounted in their closed transport and returned to the city jail for eventual disposition of their cases. Later Simon $\mathrm{Hill}$ was taken to the potters field of Stricklin Cemetary where the grave of Everest was alleged to be, he stated that this was not the grave he had helped dig. 16

15Simon Hill Affidavit taken by J.G.B.R. in 1936.

${ }^{16}$ Simon Hill Affidavit, op. cit. 


\section{CHAPTER FIVE}

\section{CONCLUSION}

The Centralia incident shows clearly the presence of three distinct mobs. The first mob was a patriotic group of marching veterans under quasi-military discipline with an adventurous and spirited leadership who were convinced that they could repeat the "Red Cross parade". episode. The second mob was composed of those legionnaires and citizens who were instantly welded together by the escalation of violence on Tower Avenue, they instantly perceived an-adversary situation and set about apprehending the IWW members who were in hiding or in flight. The third mob consisted of the lynchers of Wesley Everest, this group of murderous conspirators-acted in the name of the community and consisted primarily of the instigators of the initial action at 2nd and Tower Avenue. Each of these mobs deserves some additional attention.

As we have seen the agency of the Grant Hodge Post of the American Legion was used to begin the anti-Wobbly action because it consti.tuted a large body of vigorous young men who were -still accustomed_to: acting under military discipline. The overlapping of membership between $=$ the : - .. Citizens Protective Association, the Elks Lodge and the American Legion gave this group of men a unique position of trust in the community, a trust that grew out of commercial, social and political associations 
of a reasonably long duration and out of the patriotic fervor which characterized World War I. A tentative investigation of the membership of the Grant Hodge Post reveals a high percentage of working-class young men, the majority of who were loggers or mill workers, the very type of man the IWW felt most responsive to the message of industrial unionism. Indeed, one eyewitness reporter has stated in recent years that many of the marching veterans had carried and were carrying IWW cards in their wallets at the time of the shooting. ' If this statement is true it adds an ironic overtone to the shooting. We must futilely ask how many men who broke ranks behind Cormier and Grimm were active or inactive IWW members or sympathizers acting under impulse or out of a recently engendered military discipline. The affidavits offer us no confirmation of this important question. We only know that a group of men rushed the front door of the IWW office in the Roderick Hotel and were met with a fusilade of rifle and pistol fire from at least three and perhaps four locations. The fire which has been previously described as heavy but inaccurate caused the raiders to falter but not to stop. They broke down the door of the hall and forced the armed inhabitants to flee or seek a hiding place. Clearly they were acting wi.th firm resolve and great personal courage in pushing their attack home in the face of armed resistance that publicly and effectively cut down three of their number fatally and perhaps 15 others with wounds of one kind or another. The motivation of this 
mob can only be ascribed to the authority of their leadership, their general patriotic zeal and their failure to quickly judge what was happening to them. This was no repeat of the Red cross raid, this was a violent, preconceived attack driven home with determination and courage in the face of heavy fire. Moreover, the Legionnaires had been forewarned that their attack would be met with a spirited resistance. The circulation of the IWW handbil1. titled "We Must Appeal"2 clearly told the citizens of Centralia that the union knew what was planned for Armistice Day and whom the perpetrators of the attack. were likely to be. At least two meetings were held.with local. law enforcement officials asking protection for the IWW hall and the inhabitants thereof. Word of these meetings must have reached those planning the assault on the hall and the members of the Grant Hodge post. One can really only guess what impelled the marchers to press home their attack. The second mob was formed out of angry reaction and community consciousness offended by the shooting. Soldiers and sailors in uniform under fire from hiding men espousing an alleged alien ideology inspired citizens to react quickly to apprehend those deemed responsible for the violence. The procession of captured IWW members thru the streets guarded by bands of Legionnaires and angry citizens sometimes conveyed.by known officers of the law must have raised passions quickly. " The assignment of adversary roles was-easi $1 y$ made and acted upon.-It was simply a case of the people of Centralia against the Industrial Workers

2Text of Handbill from Pacific Northwest.Quarterly, April 1966. 3 Percy Draper Affidavit, op. cit. 
of the World. The pursuit of Wesley Everest through the backyards and alleys punctuated by pistol fire and shouts gave further impetus to the formation of the second mob. ${ }^{4}$ Once Everest was captured his trooping thru the streets of the city toward the jail gave the assembled citizenry an opportunity to publicly demonstrate their position vis a vis the Wobblies in Centralia.

It is impossible to estimate the effect of the hundreds of rumors which must have flown around the city in the hours immediately after the capture of Everest. The scene of interest shifted from the IWW hall at 2 nd and Tower to the City Jail where the captured men were housed. The second mob formed outside the jail and shouted insults and engaged in bravedo thru the afternoon. Cooler heads attempted to control events with some success. At this point the second mob had no leadership. The acknowledged leaders of the hour were at that time meeting secretly to plan the resolution of the day's events and to procure arms and ammunition to support their efforts. 5 The motivation of the second mob was clearly the recognition that a violent criminal act had been performed in the city and that extraordinary means seemed necessary to control the situation. The role played by the legionnaires was central in the second mob, the rank and file membership of the legion seemed to head the various squads-of citizens who rounded up suspected IWW activists and sympathizers, - legion members escorted the captured
${ }^{4}$ Glenn LeBaron Affidavit, 1936 taken by Irwin Goodman.
${ }^{5}$ D. E. Burel1-Affidavit-taken in 1924 by Elmer Smith. 
prisoners to the jail and formed up a kind of corporals guard at the destroyed hall. The leadership of the Legion is strangely absent from the second mob. The violence of the second mob is random violence discharged spasmatically as the situations presented themselves, leaderless and essentially motiveless save as a public affirmation of hatred and disavowal. Once incarceration had occured the second mob was content to continue public demonstration of their.beliefs but was demonstratably unwilling to act in an extra legal manner.

The third mob.acts as a representative of the second-mob to enact what they perceived as consensus of popular judgment. The third mob saw themselves as the representatives of the people of Centralia, doing their will. ${ }^{6}$ This vigilantee spirit has always lain close to the surface in the west where organized law and justice systems are comparative newcomers. The classic vigilantee situation has been an inability to swiftly deliver judicial action and punishment.-. Frustration has been the primary motivation for vigilantee action in the American West and Centralia was no_different. Frustration over the actions of social outcasts who use most cherished constitutional guarantees to commit offensive acts. Frustration of:a nation psychologically prepared to make sacrifices to defeat a foreign enemy and then denied that opportunity. Frustration-stemming:from an inability to cope with the djs- : :ruptions of the onslaught of industrial life. Frustrations growing out of the depersonalization of urbanization. This feeling of frustration

$$
{ }^{6} \text { Ibid. , Burell Affidavit. }
$$


led to the institutionalization of violence in the form of a lynch mob made up of the leaders of the Centralia business and professional community, the leaders of the Elks Lodge and the American Legion, representatives of the timber operators and mills together with a handful of zealots ready to act decisively to finish the IWW once and for all. This group of willful men armed themselves with weapons provided from the state militia arsenal and set about their bloody business.

Confidential documents which this investigator-was allowed to examine demonstrate that the Iynchers of Wesley Everest were druggists, small businessmen, lawyers, a physician and employees of the larger timber producers located in -the city.. : Most of: them were members of the citizens protective league, the Elks Lodge and had strong ties with the Grant-Hodge Post of the American Legion. Most of them were too old for active. service in the war and had participated instead in Red Cross activities, as Three Minute Men, in war bond drives and in active home front endeavors of a similar hue. - They were men of action who believed in planning and in effectiveness.

These beliefs led them to conclude the threat of the IWW in Centralia must-be stopped-decisively by the elimination of the strongest of the ${ }^{-}$local 1 adherents of the urion, Britt-Smith,-the local:.... secretary of the group. Everest was not deemed a threat, he was virtually certain candidate for the gallows having-kifled Hubbard... 
before 15 or 20 witnesses. Smith was a local resident, a man with leadership qualities. Smith had been one of the primary candidates for a beating in the planning for the first raid, now he was to be the lynching target. 7

When the mob seized Wesley Everest they thought they had Britt Smith, the mob leadership thought they were striking a death blow to the IWW in Centralia by removing once and for:all the local.Jeader, a man they feared-more than hated, it was-Wesley Everest's tragic fate that in the darkened jail his beaten form was mistaken for that of Britt Smith. The third mob was acting to achieve the goal which had been set at the meetings held in the Elks Lodge on October 20, 1919; they were driving the IWW from Centralia once and for all through the use of extreme terror-and violence.

Given the forces unleashed in Centralia on November 11, 1919, it is almost inconceivable that any other course of action could : have transpired. Historians have not-equipped themselves sufficiently to deal with questions which do not clearly-fall within their realm.. One of the most important of these questions is to attempt to probe the degree to which anxieties engendered by--events of the day=-affected the mood of the participants.

The ending of - World War - One wi thout:-a major-American sacrifice in either men or material must have had a psychological effect on

${ }^{7}$ Chaplin, The Centralia Terror. 
a population heavily exposed to British and American propaganda since 1914. Americans had to be taught to hate the "Hun" and his leader the Kaiser. and all that they stood for, "Bleeding Belgium" stories of staggering French and British losses in the trenches, the airplane, gas warfare, the submarine, all the malevolent manifestations of industrialized war unleashed by a race portrayed as merciless, cruel and devoid of humanity.

At the same time the massive epidemic of Spanish Enfluenza which was killing Americans in record numbers, this unseen and unseeable terror which struck without regard the young, the old, the rich and the poor created an anxiety that could be seen in the advertisements and news stories which appeared in the papers.

Perhaps most terrifying because of the suddenness with which it was successful was the Bolshevik Revolution in Russia. Little was known about the Bolsheviks save that they were successful in overturning an entire society in the most radical way.

Employers were able to turn the wartime hysteria and hatred engendered by the anti-German propaganda of the hour against the IWW and Socialist Party. This linking of the "Godless Hun" with the "Red Menace" successfully turned the patriotic sentiments of the civilian population against those working for change-in. America. Socialist, Anarchist and IWW propagandists were insensitive to this changing emphasis and developed no successful counter argument, rather they intensified their rhetoric and hurled defiance at their enemies 
in the most vitriolic form. Cooler heads among the Socialists were howled down at party conventions and meetings, anarchists continued to mutter about bombs and destroying the foundations of capitalist society and the IWW press took bitterly critical assessment of the war, changes for industrial peace and the growth of reaction in the country. Until we as historians can develop investigative procedures and use existing methodologies designed to penetrate this now largely subjective area we will be denied valuable insights and will merely be skimming the surface when we discuss social movements and political life.

It is possible to make some pedestrian conclusions concerning the Centralia incident. Perhaps the most obvious of these conclusions is that had the Industrial Workers of the World had a firmer base in the community the confrontation need never have taken place. IWW membership in the community itself was weak numerically and in influence, Centra]ia was a good "union=town" and could have been expected to have closed ranks against an attack; even a-verbal attack, against any of the established AFL unions in the city. The leadership, membership and targeted-unorganized lumberworkers were outside the pale of. society in Centralia. That they need not be so begs the issue.

The acceptance of legal advice from the well meaning. Elmer ... $=$ Smith was a gross error on the part of the IWW. Smith neither fully explained the law nor forewarned the union members of the possible 
consequences although it is impossible not to believe that the men involved must have felt that their actions would have only one possible end. The IWW was always more successful when it engaged in mass action maneuvers in a strike situation and avoided political confrontations. At its heart Centralia was a political confrontation dealing not with matters of labor organization but with political and social adjustments in a community. The quick ranking of virtually the entire city against the IWW demonstrates that the political judgment had already been made by the citizens and that the raid and subsequent lynching were condoned implicitly by the community.

The most obvious judgment that grows out of an investigation of the Centratia incident is the realization that growth of the industrial society was creating monumental displacement in society. These displacements were as relentless as the symbol of industrialism, the steam engine and just as difficult to control. The interests of the lumber and timber operators were not evil, they were concerns of men who viewed themselves as a kind of "super-farmer" whose task it was to harvest a crop and get it to market. Like all farmers they viewed their personal involvement with their crop in an exaggerated manner-supposing that without their. personal involvement things would not get done. 'This personal 1 involvement fed them to view any delays-:: or problems in production as an intensely personal affront.. There were no managers: to. soften this affront, there was no policy to rely upon.--An affront had to be met with personal action, this personal action meant the mobilization- of resources of all kinds. 
It was this mobilization of power of the crudest sort that caused the Centralia incident, for the only power that the dispossessed had to marshall in this case was physical power.

The result was the tragic encounter between men who should have been allies at the corner of Second and Tower in Centralia, washington, at around two o-clock in the afternoon of November 11, 1919. 


\section{A SELECTED BIBLIOGRAPHY}

\section{Manuscript Sources}

The bulk of the documentation used in the preparation of this thesis comes from a unique manuscript collection housed at the Oregon Historical Society. The extant files of the "Free Ray Becker Committee" contain affidavits from many eye witness observers of the events of November 11,1919 and constitute a remarkable corpus for the further study of the Centralia case.

\section{General Works}

Anderson, Nels. The Hobo: The Sociology of the Homeless Man. Chicago: University of Chicago Press, 1923.

Brody, David. Labor in Crisis. J. P. Lippincott: Philadelphia, 1965. Chaplin, Ralph. The Centralia Conspiracy: Chicago: General Defense Fund - IWW, 1920.

The Centralia Case. National Catholic Welfare Conference, 1930.

Chaplin, Ralph. Wobbly: The Rough and Tumble Story of an American Radical. Chicago: University of Chicago Press, 1948.

Clark, Norman. Mill Town. Seattle: University of Washington Press, 1970.

Cohen,:- Norman.- Civil Strife: in America.- Hinsdale, Illinois:-: Dryden Press, 1972.

Delaney, Ed, and Rice, M.T. The Bloodstained Trail. Seattle: The Industrial Worker, 1927. 
Draper, Theodore. The Roots of American Communism. New York: Viking Press, 1927.

Hensen, Vernon. Lumber and Labor. New York: Farrar and Rinehart, 1945.

Kipnis, Ira. The American Socialist Movement. New York: Columbia University Press, 1952.

Lampman, Ben Hur. Centralia: Tragedy and Trial. New York, DaCapo Press, 1971.

Montell, William. The Saga of Coe Ridge. - Knoxville: University of Tennessee Press, 1970.

Richards, Leonard. Gentlemen of Property and Standing. New York: Oxford University Press, 1970.

Smith, Walker. The Everett Massacre. Chicago: I.W.W. Publishing Bureau, 1916.

Thompson, Fred. The I.W.W.: Its First Fifty Years. Chicago: Industrial Workers of the World, 1955.

Tyler, Robert. Rebels of the Woods. Eugene, Oregon: University of Oregon Press, 1967. 